\title{
Immunohistochemical evaluation for P53 and VEGF (Vascular Endothelial Growth Factor) is not prognostic for long term survival in end stage esophageal adenocarcinoma
}

\author{
Avaliação imunoistoquímica do P53 e VEGF (Fator de Crescimetno Endotelial \\ Vascular) não representa fator prognóstico para sobrevida a longo prazo na \\ fase terminal do adenocarcinoma do esôfago
}

Leandro Totti Cavazzola ${ }^{1}$; André Ricardo Pereira da Rosa ${ }^{1}$; Carlos Cauduro Schirmer ${ }^{1}$; Richard Ricachenevski Gurski ${ }^{1}$; João Pedro Bueno Telles²; Fernando Mielke: Médicoi; luíse Meurer ${ }^{3}$; Maria Isabel Albano Edelweiss ${ }^{4}$; Cleber Dario Pinto Kruel ${ }^{5}$

\section{A B S T R A C T}

\begin{abstract}
Objectives: To correlate the expression of p53 protein and VEGF with the prognosis of patients submitted to curative resection to treat esophageal adenocarcinoma. Methods: Forty-six patients with esophageal adenocarcinoma, submitted to curative resection, were studied. The expressions of p53 protein and VEGF were assessed by immunohistochemistry in $52.2 \%$ and $47.8 \%$ of tumors, respectively. Results: P53 protein and VEGF expressions coincided in $26 \%$ of the cases, and no correlation between these expressions was observed. None of the clinicopathological factors showed a significant correlation with p53 protein or VEGF expressions. There was no significant association between p53 protein and VEGF expressions and long-term survival. Conclusion: The expression of p53 protein and VEGF did not correlate with prognosis in esophageal adenocarcinoma patients submitted to curative resection.
\end{abstract}

Key words: Esophageal neoplasms. Prognosis. Genes p53. Vascular endothelial growth factor A. Survivorship.

\section{INTRODUCTION}

E sophageal cancer is one of the most devastating malignant neoplasms of the gastrointestinal tract. Late diagnosis, combined with aggressive biological behavior, results in poor diagnosis for the patients who suffer from this disease'.

The possibility to establish parameters that can help predict the biological aggressiveness and the behavior of these tumors is imperative, so that one can define which patients should be submitted to curative resection, followed or not by adjuvant treatments (e.g.: chemotherapy and radiation therapy), as well as which patients might not benefit from an aggressive procedure due to unresponsiveness to neoadjuvant or adjuvant therapies ${ }^{2,4}$.

Molecular biology has revealed that most malignant tumors result from the interaction between inherited characteristics and external influences, which may cause genetic disorders in predisposed individuals, interfering with the control over the differentiation and growth of cells.

The p53 gene is located on the short arm of chromosome 17 and belongs to the group of tumor suppressor genes. Allelic losses involving this gene are associated with mutant gene forms. These mutations are one of the most frequent genetic disorders observed in malignant tumors 5 . Approximately $50 \%$ of the tumors that affect the colon, stomach, lung, breast, liver, brain and the reticuloendothelial and hematopoietic tissues contain p53 gene mutations, which shows that the inactivation of the p53 suppressor gene is nearly a universal step towards the development of human cancers ${ }^{5-7}$.

The specific analysis of esophageal carcinomas shows that p53 mutations are detected in 36 to $80 \%$ of the cases and that they apparently occur quite early in tumorigenesis, being characterized in all stages of the

Trabalho realizado no Serviço de Cirurgia Geral do Hospital de Clínicas de Porto Alegre-Universidade Federal do Rio Grande do Sul - Grupo de Cirurgia do Esôfago, Estômago e Duodeno - Porto Alegre, RS, BR.

1. Mestre e Doutor em Cirurgia pela Universidade Federal do Rio Grande do Sul. (UFRGS) RS, BR; 2. Médico - UFRGS, RS, BR; 3. Professora Assistente do Departamento de Patologia da UFRGS, RS, BR; 4. Professora Adjunta do Departamento de Patologia da UFRGS, RS, BR; 5. Professor Associado do Departamento de Cirurgia Geral - UFRGS, RS, BR. 
disease, from dysplasia to carcinoma and from Barrett's metaplasia to adenocarcinoma ${ }^{3,4,8-10}$.

Under normal physiological conditions, the formation of new blood vessels from pre-existing vessels (known as angiogenesis) is crucial for development and homeostasis. Angiogenesis occurs during embryonic development, intense menstrual cycles and, since it is an important repair mechanism, it is present in regenerative functions and after intense physical exercise, nerve injuries, wound healing, and bone growth. In these situations, it is controlled and short-lived, being balanced by factors with positive and negative angiogenic effects ${ }^{11,12}$.

Angiogenesis also plays a pivotal role in the development of solid tumors, since after a given tumor size, new blood vessels are essential for their growth, and may even contribute to the occurrence of distant metastasis by way of the dissemination of cells that loosen from the tumor and spread through the new vessels ${ }^{13}$.

The vascular endothelial growth factor (VEGF) is secreted by tumor cells and stimulates the growth of endothelial cells, usually in response to external stimuli such as hypoxia or substances secreted by the body. In patients with esophageal tumors, VEGF expression was detected in $31-60 \%$ of the cases ${ }^{14-21}$. There is a paucity of studies on the correlation between VEGF expression and prognosis in patients with esophageal carcinoma, and most of the reported cases are concerned with epidermoid carcinomas. Moreover, the results available to date are contradictory ${ }^{14-21}$.

The P53 gene seems to play a key role in the development and progression of tumors by regulating VEGF expression, but this mechanism is not fully understood yet 22,23 . Current evidence suggests that there exists an increase in the expression of VEGF mRNA due to the loss of p53 gene suppression function ${ }^{12,24}$.

Studies that assess this coexpression in patients with esophageal carcinoma are scarce, and most of the existing studies include the epidermoid histologic type, with discrepant results as far as its possible use as an independent prognostic factor are concerned ${ }^{17,19-21}$. This relationship still remains unclear, and we do not know whether it exists in a direct form, but it is possible that p53NEGF coexpression determined by immunohistochemistry (IHC) would be important in angiogenesis and metastasis. Besides, this coexpression might be used as a prognostic factor in the near future ${ }^{19,25}$.

\section{METHOD}

All patients diagnosed with esophageal adenocarcinoma treated at the Outpatient Clinic of the Group for Surgeries of the Esophagus, Stomach and Small Intestine (GCEEID) of Hospital de Clínicas de Porto Alegre (HCPA) between July 1993 and July 2001, submitted to curative resection, were prospectively assessed using a previously described protocol ${ }^{26,27}$. Patients with early postoperative death (up to 30 days after the surgery or until hospital discharge), history or presence of concomitant malignant neoplasm, neoadjuvant treatment (chemotherapy and/or radiation therapy), incomplete resection (compromised surgical margins), and patients whose paraffin blocks were not located were excluded from the study.

The study design consisted of a historical cohort, considering surgical treatment as zero time. Sociodemographic variables were used, including age, gender, smoking, alcoholism, Siewert's classification (lesion height in relation to the gastroesophageal junction $)^{28}$, types of resection surgeries performed, early postoperative death and survival of patients after the onset of treatment. The histological analysis took into account the level of tissue differentiation; depth of tumor penetration through the esophageal wall, lymph node involvement and pathological staging (TNM-UICC) ${ }^{27}$. The major study variables were p53 mutant gene and VEGF expressions. The groups were compared as to mutant p53 and VEGF expressions, using the afore-mentioned sociodemographic variables. The groups that showed these expressions were regarded as positive $(+)$, and those in which these expressions were not observed were regarded as negative (-).

As outcome, we considered deaths caused by esophageal adenocarcinoma or survival until December 2002. The patients who died of causes other than esophageal cancer or who were lost to follow-up were excluded from the study. The information about the survival of patients was obtained through their medical records and hospital and outpatient follow-up, in addition to telephone and mail contact.

Pathologic Analysis and Tissue Preparation

The analysis of the surgical specimen included the depth of tumor penetration through the esophageal wall and involvement of surgical margins, lymph node involvement, surgical limits (proximal, distal and circumferential) and level of tissue differentiation. The pathological staging of the disease (pTNM) was defined according to the International Union Against Cancer (UICC) (27). The resected surgical specimens were fixed in formalin at $10 \%$ and embedded in paraffin, according to the routine of the Division of Pathology of HCPA at the time of the procedure. Paraffin blocks were cut at a 4-ìm thickness, and later mounted onto glass slides.

\section{Antibodies, Reagents and Immunohisto- chemical Analysis}

The DO-7 mouse monoclonal antibody (Pab 1801 , Sigma Biosciences, St Louis, MO, USA) was used for identification of p53 protein. The DO-7 recognizes both the wild and mutant types of p53 protein, but due to the extremely short half-life of the wild type, the staining of the tumor cell nucleus suggests abnormal accumulation of the mutant type. 
The A-20 rabbit polyclonal antibody recognizes VEGF (Santa Cruz Biotechnology, Inc., Santa Cruz, CA, USA). It is produced against an aminoterminal epitope of human VEGF, mapping residues $1-20$ and recognizing VEGF165, VEGF189 and VEGF121.

The specimens of tumor tissue were processed for the expression of $\mathrm{p} 53$ protein and for the expression of VEGF by way of the immunohistochemical analysis routinely performed by the Division of Pathology of HCPA, using the primary antibodies described previously.

After deparaffinization and rehydration, antigen retrieval, inactivation of endogenous peroxidase activity and blocking of nonspecific reactions, the sections were incubated overnight for 12 hours at $4^{\circ} \mathrm{C}$ with a diluted solution of primary antibodies at 1:100 for p53 protein and 1:400 for VEGF. The primary antibodies were located by subsequent application of the streptavidin-biotin peroxidase complex (LSAB, Dako Corporation, Carpinteria, CA, USA) and revealed with diaminobenzidine tetrahydrochloride (Kit DAB, Dako Corporation, Carpinteria, CA, USA). All the reactions were executed with positive controls (breast cancer for p53 protein expression and placental tissue for VEGF expression).

\section{Immunohistochemical Determination of P53 Protein and VEGF Expressions}

Tumors were considered positive for $\mathrm{p} 53$ protein expression if over $10 \%$ of the tumor cell nuclei were stained in brown (p53 positive or p53+). Blocking with normal saline solution and the absence of primary antibodies were used as negative controls 29,30 .

VEGF expression was regarded as positive based on the amount and intensity of tumor cells whose cytoplasm was stained. If over $30 \%$ of tumor cells were stained (brown) more intensely than smooth muscle cells in the normal adjacent esophageal tissue, tumors were considered positive (VEGF positive or VEGF+). The smooth muscle of the lamina propria or muscularis mucosa layers were used as internal positive control as smooth muscle cells also have VEGF expression $15,16,21,31$.

The glass slides were analyzed by two researchers that were blinded to the clinical and histopathological information. The kappa statistic was used for control of interobserver agreement.

The cases with discrepant scores were conjointly reassessed on a second occasion, and an agreement was then reached.

\section{Coexpression}

Assessment of p53 Protein and VEGF

The cases were classified into three groups according to the immunohistochemical determination of p53 protein and VEGF expressions. Patients who were p53 positive and VEGF positive were classified as Group A, VEGFpositive and p53-negative or VEGF-negative and p53-positive patients as Group B, and the patients with negative reactions to both p53 protein and VEGF as Group C.

\section{Ethics}

The present study was approved by the local research ethics committee ( $n^{\circ}$. 03-100): Determination of prognostic factors in esophageal adenocarcinoma: assessment of $\mathrm{p} 53$ protein and VEGF expression.

\section{Statistical Analysis}

The correlation between p53 protein and VEGF expressions and clinicopathological characteristics were assessed by the t- test for continuous variables and by the chi-squared test for categorical variables. Fisher's exact test was used whenever necessary. Kappa statistic was used for control of interobserver agreement. The survival rate of the patients was assessed by the productlimit or Kaplan-Meier estimation. The impact of each prognostic factor on the survival rate was analyzed by the log rank test (univariate analysis). Cox proportional hazards regression (multivariate analysis) was applied to the selected variables in order to identify a combination of prognostic factors or the independent effect of individual prognostic factors on long-term survival. A $p$ value of 0.05 was considered to be statistically significant. The SPSS (Statistical Package for Social Sciences) for Windows, version 8.0, was used for the statistical analysis.

\section{RESULTS}

Between July 1993 and July 2001, 116 patients with esophageal adenocarcinoma were treated at the GCEEID/HCPA. Among these patients, 50 (43.1\%) were submitted to curative resection after the previously described preoperative assessment. It was not possible to locate the paraffin blocks for immunohistochemical analysis in four cases, which reduced the sample to 46 patients.

Of these 46 patients, 8 (17.4\%) were excluded from the survival analysis since they died while in hospital (early postoperative death). They were only considered for the prevalence study.

Of the 46 patients studied, 24 (52.2\%) were positive for p53 protein according to the immunohistochemical analysis. With regard to VEGF, 22 patients $(47.8 \%)$ were considered to present positive antibodies for this protein.

By excluding the patients with early postoperative death, we have $20(52.6 \%)$ patients regarded as p $53+$ and 19 (50\%) considered VEGF positive.

Taking into account only the patients included in the survival analysis, the mean age was 60.6 years (range: 36.6 to 78$), 30$ of whom were males $(78.9 \%)$, and most of whom were smokers (29 cases, $76.3 \%$ ). Alcoholism was observed in $47.4 \%$ of the studied patients (18 cases). Esophagectomy, 20 cases (52.6\%), was the most frequently performed surgery, with transhiatal removal of the adenocarcinoma in most cases (19 cases); total gastrectomy 
Cavazzola et al.

Immunohistochemical evaluation for P53 and VEGF (Vascular Endothelial Growth Factor) is not prognostic for long term survival in end stage esophageal 27 adenocarcinoma

Table 1 - Correlation between positive immunohistochemical results for p53 protein and VEGF expressions and clinicopathological variables.

\begin{tabular}{|c|c|c|c|c|c|c|c|c|c|c|c|}
\hline Variable & $\mathrm{n}$ & \multicolumn{2}{|c|}{ p53+ } & \multicolumn{2}{|c|}{ p53- } & $p$ & & $\begin{array}{l}F+ \\
9\end{array}$ & & & $p$ \\
\hline \multirow[t]{2}{*}{ Age } & Mean & \multicolumn{2}{|c|}{59,1} & \multicolumn{2}{|c|}{62,45} & 0,357 & \multicolumn{2}{|c|}{60,62} & \multicolumn{2}{|c|}{60,78} & 0,592 \\
\hline & SD & \multicolumn{2}{|c|}{8,93} & \multicolumn{2}{|c|}{12,91} & & \multicolumn{2}{|c|}{9,25} & \multicolumn{2}{|c|}{12,73} & \\
\hline Gender & Male & 17 & (85) & 13 & $(72,2)$ & 0,438 & 16 & $(84,2)$ & 14 & $(73,7)$ & 0,693 \\
\hline Smoking & & 15 & (75) & 14 & $(77,8)$ & 1 & 15 & $(78,9)$ & 14 & $(73,7)$ & 1 \\
\hline Alcoholism & & 10 & (50) & 8 & $(44,4)$ & 0,757 & 11 & $(57,9)$ & 7 & $(36,8)$ & 0,330 \\
\hline \multirow[t]{3}{*}{ Siewert* } & Type I & 4 & (20) & 3 & $(16,7)$ & & 4 & $(21,1)$ & 3 & $(15,8)$ & \\
\hline & Type ॥ & 9 & (45) & 8 & $(44,4)$ & 0,953 & 8 & $(42,1)$ & 9 & $(47,4)$ & 0,904 \\
\hline & Type III & 7 & (35) & 7 & $(38,9)$ & & 7 & $(36,8)$ & 7 & $(36,8)$ & \\
\hline \multirow[t]{2}{*}{ Surgery } & Esophagectomy & 9 & (45) & 11 & $(61,2)$ & 0,352 & 8 & $(42,1)$ & 12 & $(63,2)$ & 0,330 \\
\hline & Gastrectomy & 11 & (55) & 7 & $(38,8)$ & & 11 & $(57,9)$ & 7 & $(36,8)$ & \\
\hline \multirow[t]{4}{*}{ Differentiation } & Good & 1 & (5) & 5( & $27,8)$ & & 4 & $(21,1)$ & 2 & $(10,5)$ & \\
\hline & Moderate & 8 & $(40)$ & 4 & $(22,2)$ & 0,128 & 7 & $(36,8)$ & 5 & $(16,3)$ & 0,407 \\
\hline & Poor & 11 & (55) & 9 & (50) & & 8 & $(42,1)$ & 12 & $(63,2)$ & \\
\hline & None & 0 & & 0 & & & 0 & & 0 & & \\
\hline \multirow[t]{4}{*}{$T \star *$} & $\mathrm{~T} 1$ & 2 & (10) & 4 & $(22,2)$ & & 4 & $(21,1)$ & 2 & $(10,5)$ & \\
\hline & $\mathrm{T} 2$ & 3 & (15) & 3 & $(16,7)$ & 0,721 & 4 & $(21,1)$ & 2 & $(10,5)$ & 0,122 \\
\hline & T3 & 8 & (40) & 5 & $(27,8)$ & & 3 & $(15,8)$ & 10 & $(52,6)$ & \\
\hline & $\mathrm{T} 4$ & 7 & (35) & 6 & $(33,3)$ & & 8 & $(42,1)$ & 5 & $(26,3)$ & \\
\hline \multirow[t]{2}{*}{$N * *$} & No & 10 & (50) & 8 & $(44,4)$ & 0,757 & 10 & $(52,6)$ & 8 & $(42,1)$ & 0,746 \\
\hline & N1 & 10 & (50) & 10 & $(55,6)$ & & 9 & $(47,4)$ & 11 & $(57,9)$ & \\
\hline \multirow[t]{2}{*}{$M * *$} & MO & 18 & (90) & 16 & $(88,9)$ & 1 & 17 & $(89,5)$ & 17 & $(89,5)$ & 1 \\
\hline & M1 & 2 & (10) & 1 & $(11,1)$ & & 2 & $(10,5)$ & 1 & $(10,5)$ & \\
\hline Staging & 1 & 2 & (10) & 3 & $(16,7)$ & & 3 & $(15,8)$ & 2 & $(10,5)$ & \\
\hline \multirow[t]{3}{*}{$* *$} & II & 4 & (20) & 5 & $(27,8)$ & 0,472 & 6 & $(31,6)$ & 3 & $(15,7)$ & 0,462 \\
\hline & III & 12 & (60) & 8 & $(44,4)$ & & 8 & $(42,1)$ & 12 & $(63,2)$ & \\
\hline & IV & 2 & (10) & 2 & $(11,1)$ & & 2 & $(10,5)$ & 2 & $(10,6)$ & \\
\hline
\end{tabular}

$n=$ number of patients, SD=standard deviation, Data presented as $n(\%)$.

*Siewert $=$ Siewert's classification for gastric cardia adenocarcinoma ${ }^{64}$.

Type I: distal esophageal adenocarcinoma.

Type II: gastric cardia adenocarcinoma or short segments with M1 in the GEJ.

Type III: subcardial gastric adenocarcinoma with infiltration of the GEJ and distal esophagus.

** Staging according to UICC 25 .

with distal esophagectomy was reserved for the remaining 18 cases. This was the sample used for the survival analysis, including 38 patients, whose characteristics can be seen in table 1.

In the present study, no statistically significant correlation was observed between p53 protein and VEGF expressions and the variables age, gender, smoking, alcoholism, Siewert's classification, type of surgery performed, level of tissue differentiation, depth of tumor penetration through the esophageal wall (T), lymph node involvement $(\mathrm{N})$, distant metastases $(\mathrm{M})$ and pathoanatomical staging. (Table 1)

Interobserver agreement was tested by kappa statistic (kappa $=0.912$ ), with a statistical significance of $p<0.0001$, according to the immunohistochemical analysis of p53 expression, showing strong agreement between the two observers. Discrepant results were discussed conjointly until a consensus could be reached and the definitive diagnosis could be established.

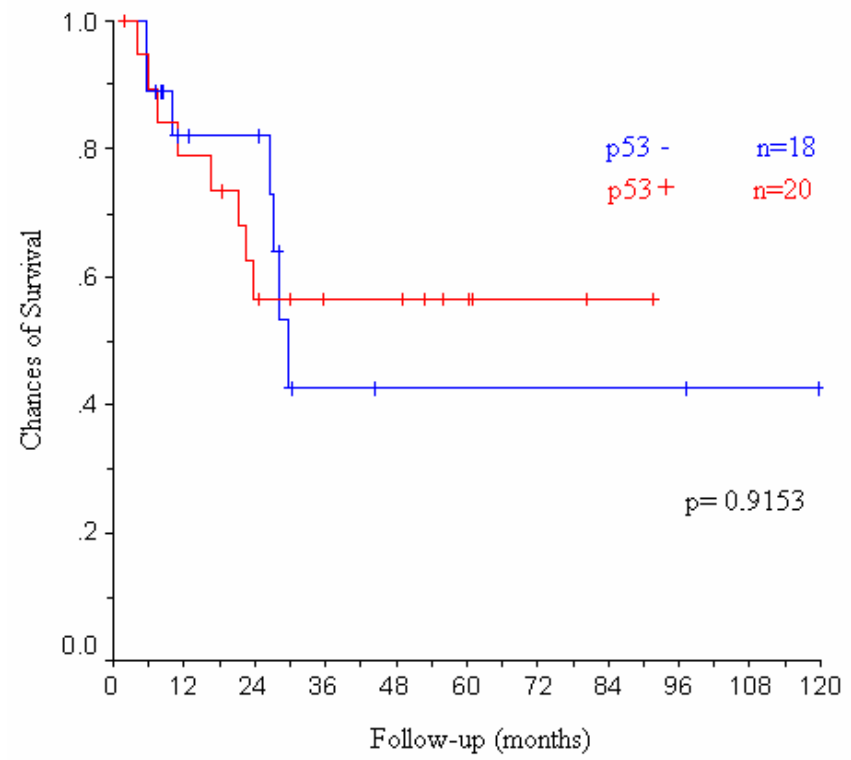

Figure 1 - Survival curve according to p53 protein expression. 
The average follow-up period was of 31.5 months (2-120 months, SD= 28.3 months). The average survival was of 70.4 months $(\mathrm{Cl}=51.9-88.5 ; \mathrm{SE}=9.4)$. Of the 38 patients studied, 15 (39.4\%) died during the follow-up period.

The expression of $\mathrm{p} 53$ protein determined by the immunohistochemical analysis showed that the average survival of $\mathrm{p} 53$ + patients was of 58.1 months $(\mathrm{Cl}=40.4-75.7 ; \mathrm{SE}=9)$, whereas for patients with a negative reaction it was of 63.22 months ( $\mathrm{Cl}=34.3-92.12, \mathrm{SE}=14.7)$. This difference was not statistically significant $(p=0.9153)$ (Figure 1$)$.

The patients who showed VEGF expression in the immunohistochemical analysis (VEGF+) had an average survival of 72 months ( $\mathrm{Cl}=53.5$ - 90.5; $\mathrm{SE}=9$ ), whereas for those with a negative reaction (VEGF-) the average survival was of 53.5 months $(\mathrm{Cl}=27.5$ - 79.4; $\mathrm{SE}=13.2)$. No statistical difference was observed between the groups $(p=0.0615)$, as shown in figure 2 .

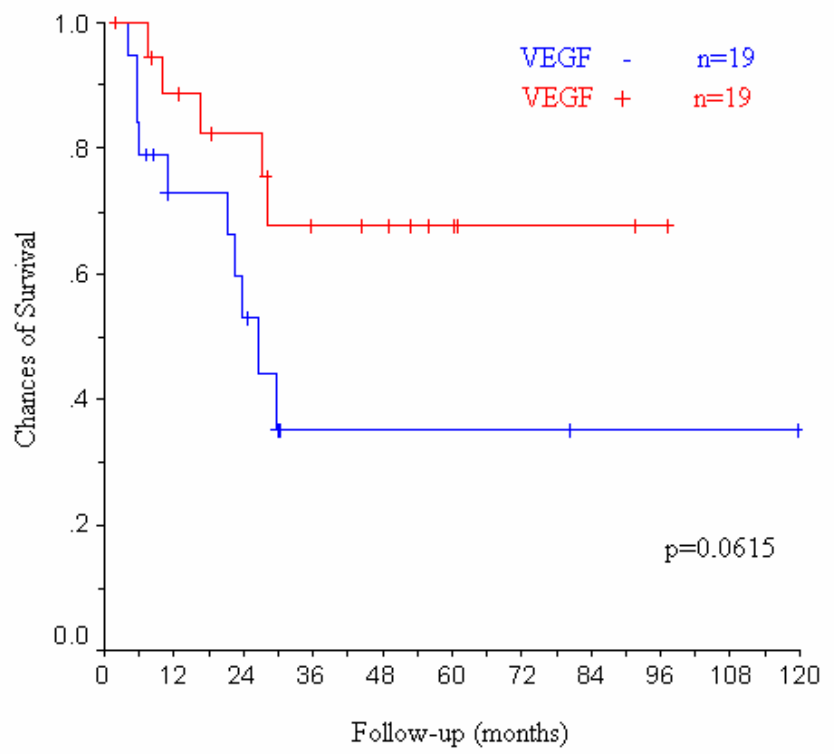

Figure 2 - Survival curve according to VEGF expression.

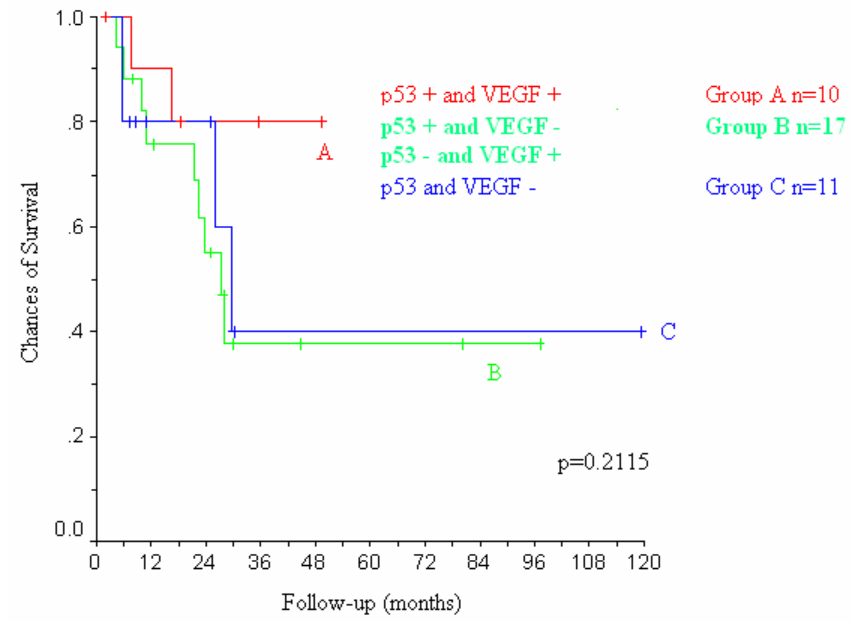

Figure 3 - Survival curve according to p53 protein and VEGF coexpression.
To check whether the p53 protein and VEGF coexpression could change the prognosis of patients with esophageal adenocarcinoma, three groups were created: Group A, for patients with positive expression of both variables (p53+ and VEGF+); Group B, in which at least one of the variables was positive (p53+ and VEGF- or p53- and VEGF+) and Group C, where neither of the variables was detected (p53- and VEGF-). The average survival for patients in group $A$ was of 75.7 months $(C l=55.9-95.5 ; \mathrm{SE}=10)$, 48 months $(\mathrm{Cl}=27.3$ - 68.7; $\mathrm{SE}=10.6)$ for group $\mathrm{B}$, and 60.15 months $(\mathrm{Cl}=20.3$ - 99.9; $\mathrm{SE}=20.3)$ for group $C$, with no statistically significant difference between the groups $(p=0.2115)$, as shown in figure 3 .

In an attempt to verify the influence of the prognostic factors regarded as highly relevant in the present study, we analyzed the depth of tumor penetration through the esophageal wall $(T)$, lymph node involvement $(\mathrm{N})$, surgical staging (TNM), level of tumor differentiation and Siewert's classification). None of these factors showed a direct effect on the survival of patients, as shown in table 2 .

\section{DISCUSSION}

The epidemiological profile of the patients in the present study is in agreement with other reference centers for esophageal adenocarcinoma throughout most of the world ${ }^{32-34}$. The predominance of male individuals older than 60 years, smokers and alcoholics observed in our patient population underscores the importance of knowing the risk factors in order to identify patients at a greater risk for esophageal cancer and to establish prophylactic strategies $32,35,36$.

Among various risk factors for esophageal adenocarcinoma described in the literature, long-established gastroesophageal reflux disease (GERD) or even the clinical presence of pyrosis seem to be implicated in a higher chance of development of this type of cancer over time ${ }^{37}$. However, given the retrospective design of the present study and the difficulty in obtain the information obtained through the medical records of the patients, we decided not to use the results regarding GERD. Likewise, obesity, also considered a risk factor for the development of esophageal adenocarcinoma ${ }^{36,38,39}$, was not assessed in the present study. The assessment of Barrett's esophagus (intestinal metaplasia observed in the esophagus of patients with chronic GERD) $)^{36,40,41}$, which is also associated with greater risk for

Table 2 - Multivariate analysis of the studied factors *.

\begin{tabular}{lccc}
\hline Variable & R R & C & p \\
\hline p53 & 1,429 & $(0,429-4,725)$ & 0,514 \\
VEGF & 0,369 & $(0,095-1,436)$ & 0,115 \\
\hline
\end{tabular}

* Adjusted according to Cox proportional hazards regression for the variables depth of tumor penetration through the esophageal wall, lymph node involvement, surgical staging, level of tumor differentiation and Siewert's classification. 
Cavazzola et al.

Immunohistochemical evaluation for P53 and VEGF (Vascular Endothelial Growth Factor) is not prognostic for long term survival in end stage esophageal adenocarcinoma

adenocarcinoma $9,38,42$ was not possible in these patients due to the advanced stage of the disease at the time of diagnosis (63.2\% patients with types III and IV), in which the mucosa with metaplastic alterations can be totally involved by tumor growth 35,43 .

The increase in the diagnosis of adenocarcinomas, in comparison to the stable occurrence rates of epidermoid carcinomas, has been reported in the western literature for years $35,36,38,42,44,45$. Controversy still exists over the fact that in western studies adenocarcinomas account for more than $50 \%$ of primary esophageal tumors, comparatively to the nearly $5 \%$ they represented in the $1970 s^{36,40}$. Some attempts to clarify this matter point out to the reduced incidence of Helicobacter pylori infection, regarded by some authors as a protective factor against the development of esophageal adenocarcinoma ${ }^{45}$, concomitantly to an increase in the prevalence of morbid obesity ${ }^{38}$. Despite the high prevalence rates reported in the literature, the confirmation of the actual increase in the incidence of Barrett's esophagus has not been an easy task. This could be explained by the dissemination and specificity of diagnostic methods, without implying any increase in pre-existing rates ${ }^{35,38,42}$. At GCEEID/ HCPA, between July 1993 and July 2001, 379 patients with epidermoid carcinoma of the esophagus and 116 patients (23.4\% of the total patient population) with adenocarcinoma of the gastroesophageal junction were studied.

Gastroesophageal junction tumors are often grouped as a single entity ${ }^{43,46-49}$, even though this classification is controversial, due to some distinct biological and histopathological characteristics pointed out by some authors ${ }^{50,51}$.

This division interferes with the postoperative histopathological classification as well. If Siewert's classification is used for gastroesophageal junction tumors, for instance, type I and II tumors should be classified (and staged) as esophageal tumors, whereas type III tumors included in the TNM staging system would be classified as gastric tumors ${ }^{28,51-54}$, which hinders the analysis of the results of preoperative assessment and of staging and treatment. In the present study, we considered TNM for esophageal tumors in the staging of patients ${ }^{43,46-49}$, as suggested by Siewert himself 53

Likewise, most studies available up to now have described epithelial tumors of the esophagus as a single disease, characterizing adenocarcinomas and epidermoid carcinomas as a single clinical entity, possibly with the aim of studying a larger patient population. Although advocated by some authors ${ }^{55-57}$, this stance is contested by several researchers, who have shown that the histological type may (and should) be considered an independent prognostic factor in patients with malignant esophageal neoplasms 51,53,58.

The resection rate of our patients $(43.1 \%-50$ among 116 patients treated throughout eight years) is lower than that reported in the literature for this type of tumor, which shows resection rates of up to $75.5 \%{ }^{53}$. Given the large amount of early perioperative deaths in our patient population (8 patients $-17.4 \%$ of the patients submitted to curative resection), we may infer that the present study includes a greater number of patients whose tumors are at a more advanced stage, with consequent worse prognosis and higher chances of postoperative complications, due to the dissemination of the disease.

The locoregional characteristics and lymph node involvement of esophageal adenocarcinomas justify the use of a transmediastinal approach in most type I and II tumors ${ }^{54}$ and an abdominal approach with extension of the resection of proximal gastrectomy to the distal esophagus in patients with type III tumors, by means of wide exposure of the esophageal hiatus and mediastinum ${ }^{52,53}$. This approach is based upon the fact that most lesions have a metastatic lymph node dissemination to the posterior lower mediastinum, juxtacardial region, and due to the small curvature of the stomach, up to the celiac trunk - sites that are easily accessed by the techniques mentioned above ${ }^{53,54}$.

The data regarding Siewert's classification show that the prevalence of tumors in the present study was as follows: type I - 7 cases (18.4\%); type II - 17 cases (44.7\%) and type III - 14 cases (36.8\%), which differs from the data obtained from the most comprehensive study conducted worldwide (51), with approximately 1,000 patients, in which $36 \%$ of tumors were of type I, $27 \%$ of type II and $37 \%$ of type III. The lowest incidence of type I tumors in the present patient population may be related to later diagnosis (63.2\% of patients with type III and IV tumors) comparatively to the correlative study (approximately $37 \%$ of patients with tumors of types III and IV), and the clinical differentiation between type I and II tumors may be hindered by the locoregional dissemination of the disease.

A great deal of effort has been channeled into finding biomarkers that can influence the progression of Barrett's esophagus in the metaplasia-dysplasiaadenocarcinoma sequence. P53 seems to be heavily implicated in this process $9,10,35,59-62$. Since p53 can "monitor" the integrity of the genome, it is regarded by many authors as "guardian of the genome" and, under normal conditions, it is activated in order to downregulate cellular proliferation in the transition from $\mathrm{G} 1$ phase to $\mathrm{S}$ phase of the cell cycle, being known as normal or wild p537,59. P53 mutations facilitate genomic instability and may predispose to the development of cell lines with remarkable nuclear defects and consequent immortality, thus leading to tumorigenesis $6,7,59$. The loss of gene suppressor function may occur due to mutation, chromosomal rearrangement, nondysjunction, gene conversion, impression or mitotic recombination. Interaction with other cell proteins or viral oncoproteins can also neutralize gene suppressor function ${ }^{6,7}$.

Nowadays, the major methods for determining p53 protein expression are immunohistochemistry and polymerase chain reaction (PCR). Although PCR is more sensitive and specific than immunohistochemistry for the detection of p53 mutations, its clinical use is less practical; however, it is routinely used in molecular biology, 6, Immunohistochemistry is easy, inexpensive and can be 
performed by any laboratory of pathology, and is used on a large scale as reported in the literature ${ }^{63-65}$. Immunohistochemistry detects phenotype mutations in p53 protein expression. Under normal conditions, the wild p53 protein has a short half-life and cannot be detected by immunoprecipitation. Nevertheless, when p53 gene mutations are observed, the half-life of this protein may increase to six hours, thus allowing identification by immunohistochemistry ${ }^{6,7}$. It should be cautiously used since the absence of p53 protein expression does not necessarily rule out the presence of mutations $s^{6,7}$. For instance, tumors with deletion of both p53 alleles can be classified as negative, also including tumors without p53 protein expression ${ }^{6}$. Moreover, some types of viruses (adenovirus, papillomavirus) can cause changes in the stability of p53 protein, allowing for its detection by immunohistochemistry and leading to false positive results ${ }^{6}$. For some authors, another limitation of immunohistochemistry is the difficulty in reproducing the analysis among different pathologists ${ }^{66}$. However, this was not observed in the present study, in which interobserver agreement was amply obtained, as confirmed by kappa statistic, which showed broad agreement between the diagnoses.

TP53 gene mutations are detected in 36 to $80 \%$ of patients with esophageal cancer and they apparently have an early development in esophageal tumorigenesis, being detected from dysplasia to carcinoma and from Barrett's metaplasia to adenocarcinoma ${ }^{8,9,67,68}$. Nonetheless, most patient populations are not classified into subgroups according to the histological tumor type, preventing a consensus of opinion about the actual role of p53 protein in esophageal adenocarcinomas $3,8,9,29,46,65,69-71$. The prevalence of p53 protein expression in the present study $(57.2 \%)$ is in agreement with that shown in the available literature.

In the present study, we found no correlation between p53 protein expression, determined by immunohistochemistry, and improvement of long-term survival. Although some studies assert that this expression is of prognostic value, its actual role in esophageal adenocarcinomas still remains unclear ${ }^{9,29}$. Given the fact that p53 protein expression is not observed in all patients with esophageal adenocarcinoma, the action of other mechanisms may be inferred ${ }^{5,29,46,57,72}$, such as the functional loss of p16, pRB and cyclin D1 genes, which can also cause DNA damage in the $\mathrm{G} 1$ phase of the cell cycle ${ }^{73-75}$.

According to the TNM staging system, p53 protein expression showed no correlation with greater tumor invasion, which indicates that, in the present study, p53 gene mutation has no statistically significant difference at these stages, occurring at early stages (I) and possibly increasing at more advanced stages (IV) of the disease ${ }^{46,}$ 60,74 , and being present in premalignant lesions $s^{5,8,46,73-75}$. The expression of p53 protein was not an independent prognostic factor in patients with adenocarcinoma and did not correlate with the other clinicopathological characteristics. In the present study, p53 protein expression was not correlated with worse prognosis, after the univariate and multivariate analyses, adjusted according to Cox proportional hazards regression for the variables depth of tumor penetration through the esophageal wall, lymph node involvement, surgical staging, level of tumor differentiation and Siewert's classification.

Solid tumors can be supplied with nutrients up to a diameter of approximately 1 to $2 \mathrm{~mm}$ by diffusion mechanisms. After this cellular volume is achieved, new vessels are necessary for tumor growth ${ }^{13,76-78}$. Among the proteins that participate in angiogenesis in different types of tumors, the vascular endothelial growth factor (VEGF) is certainly the most widely studied 79,80 .

VEGF is a specific mitogenic factor of endothelial cell proliferation produced during embryonic development and also in adult life by physiological processes for development and tissue repair (embryonic development, menstrual cycle, hypertrophic growth of muscle tissue secondary to exercise), determining the formation of new blood vessels and increasing microvascular permeability. In pathological conditions, VEGF expression is apparently greater at the sites of the tumor that are adjacent to necrotic (avascular) areas, which is consistent with the possibility that tumor angiogenesis could be induced, to some extent, by hypoxia ${ }^{13,81}$ seemingly its major stimulus ${ }^{13,22,82,83}$. VEGF is considered to be the most important parameter among angiogenic markers ${ }^{13}$.

In the present study, VEGF expression was detected in $47.8 \%$ of the patients with esophageal adenocarcinoma, which is in agreement with the results described in the literature ${ }^{15,16,17,18,19,20,21,84}$. VEGF expression did not correlate with any of the clinicopathological variables analyzed.

Most available studies on the prognostic effect of VEGF expression in patients with esophageal tumors are concerned with patients with epidermoid carcinoma of the esophagus $15,17,18,20,21,31$. In these studies, the controversy over the role of VEGF in the prognosis of these patients still persists. Few available studies have assessed the prognosis of patients with esophageal adenocarcinoma in which the detection of VEGF by immunohistochemistry could be demonstrated ${ }^{14,16}$. In these studies, no consensus was reached on the actual prognostic factor of VEGF expression. In the present study, VEGF expression was not associated with improvement of long-term prognosis in the univariate or multivariate analyses adjusted for depth of tumor penetration through the esophageal wall, lymph node involvement, surgical staging, level of tumor differentiation and Siewert's classification.

In a study conducted with patients with esophageal adenocarcinoma that assessed VEGF expression and its correlation with prognosis ${ }^{14}$, tumor vascularization was more pronounced at earlier stages of the disease and correlated with better survival rates. However, in the present study, when we excluded patients with superficial tumors (accounting for approximately $30 \%$ of the patient population), vascularization did not show a prognostic value, and even though vascularization is correlated with VEGF 
expression, we did not observe an overall prognostic significance. These data allow us to conclude that angiogenesis is pronounced in premalignant lesions and in early carcinomas, constituting an early event in neoplastic progression ${ }^{5,85,86}$ and that at advanced stages, the established prognostic factors (depth of tumor penetration through the esophageal wall, lymph node involvement, level of tumor differentiation, distant metastasis) are possibly more important than angiogenesis alone, for the determination of prognosis $21,79,87,88$.

When the study group consists of patients whose tumors are at an early stage of development and whose follow-up period will be consequently longer, the difference between the long-term survival curves will probably be greater, thus determining the prognostic value. VEGF expression appears to be useful for patients at the initial stages of the disease ${ }^{89}$. An approach to be adopted in these cases would be the implementation of more aggressive therapies (e.g.: neoadjuvant therapy), in VEGF+ patients, since they could present metastasis quite early and consequently have a worse prognosis 21,90-92.

Tumor development and growth at advance stages (as in the present study) seem to occur independently of VEGF expression, whereas the initial metastatic event may be VEGF-dependent or be at least correlated with this factor ${ }^{86,89}$. At advanced stages, angiogenic events are less pronounced ${ }^{14,79,85}$, and because of that, their influence over the prognosis of patients may not be demonstrated in studies with a large patient population with advanced carcinomas.

Clinical and experimental evidence has suggested that p53 plays an important role in the regulation of VEGF expression ${ }^{17,24,93}$. The expression of p53 protein could be associated with an increase in VEGF production $22,23,25$, even though recent studies specifically concerned with esophageal carcinoma (with no distinction of histological type) have not successfully shown such association ${ }^{19,21,94,95}$. The coexpression of these proteins would be associated with worse prognosis ${ }^{17,19,96}$.

In the present study, the coexpression between p53 protein and VEGF detected by immunohistochemistry was observed in 12 patients (26\% of the cases), and this association was not correlated with worse prognosis or with the presence of distinct clinicopathological characteristics in groups with and without expression of the proteins.

Our conclusion is that in the present study p53 protein was expressed in 24 patients (52.2\%) and its expression was no related to worse prognosis, and that VEGF expression was detected in 22 patients (47.2\%). No correlation was observed between VEGF expression (determined by immunohistochemistry) and long-term survival. The association between the coexpression of p53 protein determined by immunohistochemistry and VEGF did not correlate with prognosis in the present study. ${ }^{7}$ Therefore, in the studied patients, the immunohistochemical analysis of p53 protein and VEGF did not prove to be a prognostic factor for long-term survival.

\title{
RE S U M O
}

\begin{abstract}
Objetivo: Correlacionar a expressão do p53 e VEGF com o prognóstico de pacientes submetidos à operação curativa para tratar adenocarcinoma do esôfago. Método: Foram estudados 46 pacientes com adenocarcinoma de esôfago, submetidos à ressecções curativas. As expressões do p53 e VEGF foram assessadas por imunoistoquímica em $52.2 \%$ e $47.8 \%$ dos tumors, respectivamente . Resultados: As expressões de ambos coincidiram em $26 \%$ dos casos sem correlação entre elas. Os fatores clinicopatológicos estudados não mostraram correlação significante. Não houve associação significante entre as expresses do p53 e VEGF na sobrevida a longo prazo. Conclusão: As expressões do p53 e VEGF não se correlacionaram com o prognóstico do adenocarcinoma do esôfago nos pacientes operados com ressecções curativas.
\end{abstract}

Descritores: Neoplasias esofágicas. Prognóstico. Genes p53. Fator A de crescimento do endotélio vascular. Sobrevida.

\section{REFERENCES}

1. Blot WJ. Cancer of the esophagus: its causes and changing patterns of occurrence. In: Perry MC, Whippen D, editors. Proceedings of the 33rd American Society of Clinical Oncology - Educational Book; 1997 May 17-20; Denver, USA. USA, American Society of Clinical Oncology; 1997. p. 159-63.

2. Ruol A. Multimodality treatment for non-metastatic cancer of the thoracic esophagus. Dis Esophagus. 1996; 9(1): 39-55.
3. Ribeiro Jr U, Filkelstein SD, Safatle-Ribeiro AV, Landreneau RJ, Clarke MR, Bakker A, Swalsky PA, Gooding WE, Posner MC. p53 sequence analysis predicts treatment response and outcome of patients with esophageal carcinoma. Cancer. 1998; 83(1): 7-18.

4. Fondevila C, Metges JP, Fuster J, Grau JJ, Palacín A, Castells A, Volant A, Pera M. p53 and VEGF expression are independent predictors of tumour recurrence and survival following curative resection of gastric cancer. Br J Cancer. 2004; 90(1): 206-15. 
5. Jenkins GJ, Doak SH, Parry JM, D'Souza FR, Griffiths AP, Baxter JN Genetic pathways involved in the progression of Barrett's metaplasia to adenocarcinoma. Br J Surg. 2002; 89(7): 824-7.

6. Chang F, Syrjänen S, Tervahauta A, Syrjänen K. Tumourigenesis associated with the p53 tumour suppressor gene. $\mathrm{Br} J$ Cancer. 1993; 68(4): 653-61.

7. Steele RJ, Thompson AM, Hall PA, Lane DP. The p53 tumor suppressor gene. Br J Surg. 1998; 85(11): 1460-7.

8. Casson AG, Evans SC, Gillis A, Porter GA, Veugelers P, Darnton SJ, Guernsey DL, Hainaut P. Clinical implications of p53 tumo suppressor gene mutation and protein expression in esophageal adenocarcinomas: results of a ten-year prospective study. J Thorac Cardiovasc Surg. 2003; 125(5): 1121-31.

9. Dolan K, Walker SJ, Gosney J, Field JK, Sutton R. TP53 mutations in malignant and premalignant Barrett's esophagus. Dis Esophagus. 2003; 16(2): 83-9.

10. Merola E, Mattioli E, Minimo C, Zuo W, Rabitti C, Cicala M, Caviglia $R$, Pollice L, Gabbrielli A, Giordano A, Claudio PP. Immunohistochemical evaluation of pRb2/p130, VEGF, EZH2, p53, p16, p21 waf-1, p27, and PCNA in Barrett's esophagus. J Cell Physiol. 2006; 207(2): 512-9

11. Folkman J. Seminars in Medicine of the Beth Israel Hospital, Boston Clinical applications of research on angiogenesis. N Engl J Med. 1995: 333(26): 1757-63.

12. Ferrara N. Vascular endothelial growth factor. Eur J Cancer. 1996; 32A(14): 2413-22

13. Gaiso MK. Antiangiogenesis: a new anticancer therapy? Medscape Oncology 1999; 2: 1-5. Available from http://www.medscape.com/ viewarticle/408446

14. Coulevard A, Paraf F, Gratio V, Scoazec JY, Hénin D, Degott C, Fléjou JF. Angiogenesis in the neoplastic sequence of Barrett's oesophagus. Correlation with VEGF expression. J Pathol. 2000; 192(1): 14-8

15. Inoue K, Ozeki $Y$, Suganuma T, Sugiura $Y$, Tanaka S. Vascular endothelial growth factor expression in primary esophageal squamous cell carcinoma. Association with angiogenesis and tumor progression. Cancer. 1997; 79(2): 206-13.

16. Kitadai Y, Haruma K, Tokutomi T, Tanaka S, Sumii K, Carvalho M, Kuwabara M, Yoshida K, Hirai T, Kajiyama G, Tahara E. Significance of vessel count and vascular endothelial growth factor in human esophageal carcinomas. Clin Cancer Res. 1998; 4(9): 2195-200.

17. Uchida S, Shimada Y, Watanabe G, Tanaka H, Shibagaki I, Miyahara $\mathrm{T}$, Ishigami S, Imamura M. In oesophageal squamous cell carcinoma vascular endothelial growth factor is associated with p53 mutation, advanced stage and poor prognosis. Br J Cancer. 1998; 77(10): 1704-9.

18. Arii S, Mori A, Uchida S, Fujimoto K, Shimada Y, Inamura M. Implication of vascular endothelial growth factor in the development and metastasis of human cancers. Human Cell. 1999; 12(1): $25-30$

19. Koide N, Nishio A, Hiraguri M, Hanazaki K, Adachi W, Amano J. Coexpression of vascular endothelial growth factor and p53 protein in squamous cell carcinoma of the esophagus. Am J Gastroenterol. 2001; 96(6): 1733-40

20. Shih $\mathrm{CH}$, Ozawa S, Ando N, Ueda M, Kitajima M. Vascular endothelial growth factor expression predicts outcome and lymph node metastasis in squamous cell carcinoma of the esophagus. Clin Cancer Res. 2000; 6(3): 1161-8.

21. Rosa AR, Schirmer CC, Gurki RR, Meurer L, Edelweiss Ml, Kruel CP. Prognostic value of $\mathrm{p} 53$ protein expression and vascular endothelial growth factor expression in resected squamous cell carcinoma of the esophagus. Dis Esophagus. 2003; 16(2): 112-8.

22. Kieser A, Weich HA, Brandner G, Marmé D, Kolch W. Mutant p53 potentiates protein kinase $C$ induction of vascular endothelial growth factor expression. Oncogene. 1994; 9(3): 963-9.

23. Mulkhopadhyay D, Tsioskas L, Sukhatame VP. Wild-type p53 and $v$-Src exert opposing influences on human vascular endothelial growth factor gene expression. Cancer Res. 1995; 55(24): 6161-5.

24. Maeda K, Kang SM, Onoda N, Ogawa M, Sawada T, Nakata B, Kato Y, Chung YS, Sowa M. Expression of p53 and vascular endothelial growth factor associated with tumor angiogenesis and prognosis in gastric cancer. Oncology. 1998; 55(6): 594-9.
25. Maeda K, Kang S, Onoda N, Ogawa M, Kato Y, Sawada T, Chung $\mathrm{KH}$. Vascular endothelial growth factor expression in preoperative biopsy specimens correlates with disease recurrence in patients with early gastric carcinoma. Cancer. 1999; 86(4): 566-71.

26. Rosa AR, Schirmer CC, Gurski RR, Brentano L, Kruel CD. Survival and prognostic factors in patients with resected epidermoid oesophageal carcinoma. Int Surg. 1999; 84(3):193-8.

27. Cavazzola LT, Telles JPB, Pesce G, et al. Delayed cervical esophagogastric anastomosis. In: Pinotti HW, Ceconello I, Felix VN, Oliveira MA, editors. Recent advances in diseases of the esophagus. Bologna: Monduzzi Editore; 2001. p. 579-85.

28. Siewert JR, Stein HJ. Classification of adenocarcinoma of the oesophagogastric junction. Br J Surg. 1998; 85(11): 1457-9.

29. Coggi G, Bosari S, Roncalli M, Graziani D, Bossi P, Viale G, et al. p53 protein accumulation and p53 gene mutation in esophageal carcinoma. A molecular and immunohistochemical study with clinicopathologic correlations. Cancer. 1997; 79(3): 425-32.

30. Kajyiama Y, Hattori K, Tomita N, Amano T, Iwanuma Y, Narumi K, Udagawa $H$, Tsurumaru M. Histopathologic effects of neoadjuvant therapies for advanced squamous cell carcinoma of the esophagus: multivariate analysis of predictive factors and p53 overexpression. Dis Esophagus. 2002; 15(1): 61-6.

31. Koide $N$, Nishio A, Kono T, Yazawa K, Igarashi J, Watanabe $H$, Nimura Y, Hanazaki K, Adachi W, Amano J. Histochemical study of vascular endothelial growth factor in squamous cell carcinoma of the esophagus. Hepatogastroenterology. 1999; 46(26): 952-8.

32. Engel LS, Chow WH, Vaughan TL, Gammon MD, Risch HA, Stanford $\mathrm{JL}$, et al. Population attributable risks of esophageal and gastric cancers. J Natl Cancer Inst. 2003; 95(18):1404-13.

33. Eloubedi MA, Desmond R, Arguedas MR, Reed CE, Wilcox CM. Prognostic factors for the survival of patients with esophageal carcinoma in the U.S.: the importance of tumor length and lymph node status. Cancer. 2002; 95(7): 1434-43.

34. Ikeda M, Natsugoe S, Ueno S, Baba M, Aikou T. Significant hostand tumor-related factors for predicting prognosis in patients with esophageal carcinoma. Ann Surg. 2003; 23(2)8: 197-202.

35. Altorki NK, Oliveria S, Schrump DS. Epidemiology and molecular biology of Barrett's adenocarcinoma. Semin Surg Oncol. 1997; 13(4): $270-80$.

36. Slehria S, Sharma P. Barrett's Esophagus. Curr Opin Gastroenterol 2003; 19(4): 387-93. Available at www.medscape.com/viewarticle/457731.

37. Lagergren J, Bergström R, Lindgren A, Nyrén O. Symptomatic gastroesophageal reflux as a risk factor for esophageal adenocarcinoma. N Engl J Med. 1999; 340(11): 825-31.

38. Cameron AJ. Epidemiology of Barrett's esophagus and adenocarcinoma. Dis Esophagus. 2002; 15(2):106-8.

39. Brown LM, Swanson CA, Gridley G, Swanson GM, Schoenberg JB, Greenberg RS, Silverman DT, Pottern LM, Hayes RB, Schwartz $A G$, et al. Adenocarcinoma of the esophagus: role of obesity and diet. J Natl Cancer Inst. 1995; 87(2): 104-9.

40. Gurski RR, Petters JH, Hagen JA, DeMeester SR, Bremner CG, Chandrasoma PT, . Barrett's esophagus can and does regress after antireflux surgery: a study of prevalence and predictive features. J Am Coll Surg. 2003; 196(5): 706-12; discussion 712-3.

41. Spechler SJ. Clinical practice. Barrett's esophagus. N Engl J Med. 2002; 346(11): 836-42.

42. Watson A. Barrett's oesophagus - 50 years on. Br J Surg. 2000; 87(5): 529-31

43. Ruol A, Parenti A, Zaninotto G, Merigliano S, Costantini M, Cagol $M$, et al. Intestinal metaplasia is the probable common precursor of adenocarcinoma in Barrett esophagus and adenocarcinoma of the gastric cardia. Cancer. 2000; 88(11): 2520-8.

44. Blot WJ, Devesa SS, Kneller RW, Fraumeni JF Jr. Rising Incidence of adenocarcinoma of the esophagus and gastric cardia. JAMA. 1991; 265(10): 1287-9.

45. Hansen S, Melby KK, Aase S et al. Role of smoking and Helicobacter pylori infection in aetiology of cardia versus non-cardia gastric cancer [abstract]. Gastroenterology. 2000; 118: A75.

46. Ireland AP, Shibata DK, Chandrasoma P, Lord RVN, Petters JH, DeMeester TR. Clinical significance of p53 mutations in adenocarcinoma of the esophagus and cardia. Ann Surg. 2000; 231(2): 179-87 
Cavazzola et al.

47. Wijnhoven BPL, Siersema PD, van Dekken $H$, Tilanus HW. Adenocarcinomas of the distal oesophagus and gastric cardia are one clinical entity. Rotterdam Oesophageal Tumour Study Group. Br J Surg. 1999; 86(4): 529-35.

48. van Dekken $\mathrm{H}$, Alers J, Riegman PH, Rosenberg C, Tilanus HW, Vissers K. Molecular cytogenetic evaluation of gastric cardia adenocarcinoma and precursor lesions. Am J Pathol. 2001; 158(6): 1961-7.

49. Bruno L, Nesi G, Montinaro F, Carassale G, Lassig R, Boddi V, Bechi $P$, Cortesini $C$. Clinicopathologic findings and results of surgical treatment in cardiac adenocarcinoma. J Surg Oncol. 2000; 74(1): 33-5.

50. Taniére $P$, Martel-Planche G, Maurici D, Lombard-Bohas C, Scoazec JY, Montesano R, Berger F, Hainaut P. Molecular and clinical differences between adenocarcinomas of the esophagus and gastric cardia. Am J Pathol. 2001; 158(1): 33-40.

51. Siewert JR, Feith M, Werner M, Stein HJ, Brennan MF, Wong J. Adenocarcinoma of the esophagogastric junction: results of surgical therapy based on anatomical/topographic classification in 1,002 consecutive patients. Ann Surg. 2000; 232(3): 353 61.

52. Hardiwick RH, Williams GT. Staging of oesophageal adenocarcinoma. Br J Surg. 2002; 89(9): 1076-7.

53. Siewert JR, Stein HJ, Feith M, Bruecher BLDM, Bartels H, Fink U. Histologic tumor type is an independent prognostic parameter in esophageal cancer: lessons from more than 1,000 consecutive resections at a single center in the Western world. Ann Surg. 2001; 234(3): 360-7; discusiion 368-9.

54. Siewert JR, Stein HJ, Sendler A, et al. Esophageal cancer: clinical management. In: Kelsen DA, ed. Principles and practice of gastrointestinal oncology. Philadelphia: Lippincot Williams \& Williams; 2001. 976 p.

55. Lerut T, DeDeyn P, Coosemans W, Van Raemdonck D, Scheys I, LeSaffre E. Surgical strategies in esophageal carcinoma with emphasis on radical lymphadenectomy. Ann Surg. 1992; 216(5): 583-90.

56. Hagen JA, Peters JH, DeMeester TR. Superiority of extended en bloc esophagogastrectomy for carcinoma of the lower esophagus and cardia. J Thorac Cardiovasc Surg. 1993; 106(5): 850-8; discussion 858-9.

57. Alexandrou A, Davis PA, Law S, Murthy S, Whooley BP, Wong J. Squamous cell carcinoma and adenocarcinoma of the lower third of the esophagus and gastric cardia: similarities and differences. Dis Esophagus. 2002; 15(4): 290-5.

58. Bollschweiler E, Schröder W, Hölscher AH, Siewert JR. Preoperative risk analysis in patients with adenocarcinoma or squamous cell carcinoma of the esophagus. Br J Surg. 2000; 87(8): 1106-10.

59. Shinohara $M$, Aoki $T$, Sato $S$, Takagi $Y$, Osaka $Y$, Koyanagi $Y$, Hatooka S, Shinoda M. Cell cycle-regulated factors in esophageal cancer. Dis Esophagus. 2002; 15(2):149-54

60. Audrézet MP, Robaszkiewicz M, Mercier B, Nousbaum JB, Hardy E, Bail JP, Volant A, Lozac'h P, Gouérou H, Férec C. Molecular analysis of the TP53 gene in Barrett's adenocarcinoma. Hum Mutat. 1996; 7(2): 109-13.

61. Hanas J, Lerner MR, Lightfoot SA, Raczkowski C, Kastens DJ, Brackett DJ, Postier RG. Expression of the cyclin-dependent kinase inhibitor p21waf1/cip1 and p53 tumor suppressor in dysplastic progression and adenocarcinoma in Barrett esophagus. Cancer. 1999; 86(5): 756-63.

62. Kobayashi S, Koide $Y$, Endo M, Isono K, Ochiai T. The p53 gene mutation is of prognostic value in esophageal squamous cell carcinoma patients in unified stages of curability. Am J Surg. 1999; 177(6): 497-502.

63. Fagundes RB, Mello CR, Tollens $P$, Pütten AC, Wagner MB, Moreira LF, Barros SG. p53 protein in esophageal mucosa of individuals at high risk of squamous cell carcinoma of the esophagus. Dis Esophagus. 2001; 14(3-4):185-90.

64. Ikeguchi M, Saito H, Katano K, Tsujitani S, Maeta M, Kaibara N. Clinicopathologic significance of the expression of mutated p53 protein and the proliferative activity of cancer cells in patients with esophageal squamous cell carcinoma. J Am Coll Surg. 1997; 185(4): 398-403.
65. Kanamoto A, Kato $H$, Tachimori $Y$, Watanabe $H$, Nakanishi $Y$, Kondo H, Yamaguchi H, Gotoda T, Muro K, Matsumura Y. No prognostic significance of p53 expression in esophageal squamous cell carcinoma. J Surg Oncol. 1999; 72(2): 94-8.

66. Sarbia M, Vereet PR, Röher HD. Relevant prognostic biological and morphological factors in esophageal cancer. In: Perachia A, Rosati R, Bonavina L, Fumagalli U, Bona S, Chella B, editors. Recent advances in diseases of the esophagus. Bologna: Monduzzi Editore; 1996. p.15-8.

67. Brown JM, Wouters BG. Apoptosis, p53, and tumor cell sensitivity to anticancer agents. Cancer Res. 1999; 59(7): 1391-9.

68. Mathew R, Arora S, Khanna R, Mathur M, Shukla NK, Ralhan R. Alterations in p53 and pRb pathways and their prognostic significance in oesophageal cancer. Eur J Cancer. 2002; 38(6): 832-41.

69. Vijeyasingam R, Darnton SJ, Jenner K, Allen CA, Billingham C, Matthews HR. Expression p53 protein in oesophageal carcinoma: clinicopathological correlation and prognostic significance. Br J Surg. 1994; 81(11): 1623-6.

70. Patel DD, Bhatavdekar JM, Chikhlikar PR, Patel YV, Shah NG, Ghosh N, Suthar TP, Balar DB. Clinical significance of p53, nm23, and bcl-2 in T3-4N1M0 oesophageal carcinoma: an immunohistochemical approach. J Surg Oncol. 1997; 65(2): 111 -

71. Casson AG, Tammemagi M, Eskandarian S, Redston M, McLaughlin J, Ozcelik H. p53 alterations in oesophageal cancer: association with clinicopathological features, risk factors, and survival. Mol Pathol. 1998; 51(2): 71-9.

72. Younes M, Ertan A, Lechago J. p53 protein and malignant progression in Barrett's metaplasia (Barrett's esophagus). Am J Gastroenterol. 2003; 98(5): 1200-1; author reply 1201.

73. Wu TT, Watanabe T, Heitmiller R, Zahurak M, Forastiere AA, Hamilton SR. Genetic alterations in Barrett esophagus and adenocarcinomas of the esophagus and esophagogastric junction region. Am J Pathol. 1998; 153(1): 287-94.

74. Wijnhoven BP, Tilanus HW, Dinjens WN. Molecular biology of Barrett's adenocarcinoma. Ann Surg. 2001; 233(3): 322-37.

75. Adulaimi D, Jankowki J. Barrett's esophagus: an overview of the molecular biology. Dis Esophagus. 1999; 12(3): 177-80.

76. Ellis LM, Fidler IJ. Angiogenesis and metastasis. Eur J Cancer. 1996; $32 \mathrm{~A}(14): 2451-60$.

77. Folkman J. What is the evidence that tumors are angiogenesis dependent? J Natl Cancer Inst. 1990; 82(1):4-6.

78. Folkman J. How is blood vessel growth regulated in normal and neoplastic tissue? G.H.A. Clowes memorial Award lecture. Cancer Res. 1986; 46(2):467-73.

79. Poon RTP, Fan ST, Wong J. Clinical significance of angiogenesis in gastrointestinal cancers - a target of novel prognostic and therapeutic approaches. Ann Surg. 2003; 238(1): 9-28.

80. Nicosia R. What is the role of vascular endothelial growth factorrelated molecules in tumor angiogenesis. Am J Pathol. 1998; 153(1): 11-6.

81. Thomas KA. Vascular endothelial growth factor, a potent and selective angiogenic agent. J Biol Chem. 1996; 271(2): 603-6.

82. Vermeulen PB, Gasparini G, Fox SB, Toi M, Martin L, McCulloch $P$, Pezzella F, Viale G, Weidner N, Harris AL, Dirix LY. Quantification of angiogenesis in solid human tumors: an international consensus on the methodology and criteria of evaluation. Eur J Cancer. 1996; 32A(14): 2474-84.

83. Shweiki D, Itin A, Soffer D, Keshet E. Vascular endothelial growth factor induced by hypoxia may mediate hypoxia-initiated angiogenesis. Nature. 1992; 359(6398): 843-5.

84. Shimada H, Takeda A, Nabeya Y, Okazumi SI, Matsubara H, Funami $Y$, et al. Clinical significance of serum vascular endothelial growth factor in esophageal squamous cell carcinoma. Cancer. 2001; 92(3): 663-9.

85. Wilson KT. Angiogenic markers, neovascularization and malignant deformation of Barrett's esophagus. Dis Esophagus. 2002; 15(1): 16-21.

86. Rak J, Yu JL. Oncogenes and tumor angiogenesis: the question of vascular "supply" and vascular "demand". Semin Cancer Biol. 2004; 14(2): 93-104. 
87. DeMeester SR. Lymph node involvement in esophageal adenocarcinoma: if you see one, have you seen them all? J Thorac Cardiovasc Surg. 2003; 126(4): 947-9.

88. Lerut T, Coosemans W, Decker G, De Leyn P, Ectors N, Fieuws S, et al. Extracapsular lymph node involvement is a negative prognostic factor in T3 adenocarcinoma of the distal esophagus and gastroesophageal junction. J Thorac Cardiovasc Surg. 2003; 126(4): 1121-7.

89. Sato F, Shimada Y, Watanabe G, Uchida S, Makino T, Imamura M. Expression of vascular endothelial growth factor, matrix metalloproteinase-9 and E-cadherin in the process of lymph node metastasis in oesophageal cancer. Br J Cancer. 1999; 80(9):136672.

90. Torres C, Wang H, Tuner SJ, Shahsafaei A, Odze RD. Prognostic significance and effect of chemoradiotherapy on microvessel density in esophageal Barrett's adenocarcinoma and squamous cell carcinoma. Human Pathol. 1999; 30(7): 753-8.

91. McDonnell CO, Bouchier-Hayes DJ, Toomey D, Foley D, Kay EW, Leen E, Walsh TN. Effect of neoadjuvant chemoradiotherapy on angiogenesis in oesophageal cancer. Br J Surg. 2003; 90(11): 13738.

92. McDonnell CO, Harvey JH, Bouchier-Hayes DJ, Walsh NJ. Effect of multimodality therapy on circulating vascular endothelial growth factor levels in patients with esophageal cancer. Br J Surg. 2001; 88(8): 1105-9

93. Han U, Can OI, Han S, Kayhan B, Onal BU. Expressions of p53, VEGF C, p21: could they be used in preoperative evaluation of lymph node metastasis of esophageal squamous cell carcinoma? Dis Esophagus. 2007; 20(5): 379-85.
94. Ahn MJ, Jang SJ, Park YW, Choi JH, Oh HS, Lee CB, Paik HK, Park CK. Clinical prognostic values of vascular endothelial growth factor, microvessel density, and p53 expression in esophageal carcinomas. J Korean Med Sci. 2002; 17(2): 201-7.

95. Merola E, Mattioli E, Minimo C, Zuo W, Rabitti C, Cicala M, Caviglia R, Pollice L, Gabbrielli A, Giordano A, Claudio PP. Immunohistochemical evaluation of pRb2/p130, VEGF, EZH2, p53, p16, p21waf-1, p27, and PCNA in Barrett's esophagus. J Cell Physiol. 2006; 207(2):512-9

96. Montero E, Abreu C, Tonino P. Relationship between VEGF and p53 expression and tumor cell proliferation in human gastrointestinal carcinomas. J Cancer Res Clin Oncol. 2008; 134(2):193-201. Epub 2007 Jul 17.

Recebido em 22/08/2008

Aceito para publicação em 28/10/2008

Conflito de interesse: nenhum

Fonte de financiamento: nenhuma

\section{Como citar este artigo:}

Cavazzola LT, Rosa ARP, Schirmer AC, Gurski RR, Telles JPB, Mielk L, Edelweiss MIA, Kruel CDP. Immunohistochemical evaluation for p53 and VEGF (Vascular Endothelial Growth Factor) is not prognostic for long term survival in end stage esophageal adenocarcinoma. Rev Col Bras Cir. [periódico na Internet] 2009; 36(1). Disponível em URL: http:/ /www.scielo.br/rcbc

\section{Correspondence to:}

Leandro Totti Cavazzola

E-mail: cavazzola@gmail.com 